\title{
Microlunatus panaciterrae sp. nov., a $\beta$-glucosidase-producing bacterium isolated from soil in a ginseng field
}

Correspondence

Min-Ho Yoon

mhyoon@cnu.ac.kr

\author{
Dong-Shan An, ${ }^{1}$ Wan-Taek $\mathrm{Im}^{1}$ and Min-Ho Yoon ${ }^{2}$
}

\begin{abstract}
1Department of Biological Sciences, Korea Advanced Institute of Science and Technology, 373-1 Guseong-dong, Yuseong-gu, Daejeon 305-701, Republic of Korea

${ }^{2}$ Department of BioEnvironmental Chemistry, College of Agriculture and Life Sciences, Chungnam National University, Gung-dong 22, Yuseong-gu, Daejeon 305-764, Republic of Korea
\end{abstract}

During a study of bacterial populations that metabolize ginsenoside $\mathrm{Rb} 1$ to $\mathrm{Rg} 3, \mathrm{Rh} 2$ or compound $\mathrm{K}$, a large number of $\beta$-glucosidase-producing novel strains from various sources, such as human faeces, environmental soils, wastewater sludge and different types of soil used for ginseng cultivation, were screened. One of these $\beta$ glucosidase-producing isolates, designated strain Gsoil $954^{\mathrm{T}}$ (isolated from soil used for ginseng cultivation) was characterized in this study. On the basis of $16 \mathrm{~S}$ rRNA gene sequence data, this strain was shown to represent a novel species of the genus Microlunatus in the family Propionibacteriaceae. The genus Microlunatus was first described on the basis of the characteristics of the type species of Microlunatus phosphovorus by Nakamura et al. (1995). At the time of writing, the genus also contained another recently described species, Microlunatus ginsengisoli (Cui et al., 2007). In this study, we characterized a novel Microlunatus-like strain, Gsoil $954^{\mathrm{T}}$, which was isolated in South Korea from soil used for ginseng cultivation.

For strain isolation, a sample of soil used for ginseng cultivation was suspended in $50 \mathrm{mM}$ phosphate buffer

The GenBank/EMBL/DDBJ accession number for the 16S rRNA gene sequence of strain Gsoil $954^{\top}$ is AB271051.
( $\mathrm{pH} 7.0)$ and the suspension was spread on modified R2A agar plates (containing, $\mathrm{I}^{-1}, 0.25 \mathrm{~g}$ tryptone, $0.25 \mathrm{~g}$ peptone, $0.25 \mathrm{~g}$ yeast extract, $0.125 \mathrm{~g}$ malt extract, $0.125 \mathrm{~g}$ beef extract, $0.25 \mathrm{~g}$ Casamino acids, $0.25 \mathrm{~g}$ soytone, $0.5 \mathrm{~g}$ glucose, $0.3 \mathrm{~g}$ soluble starch, $0.2 \mathrm{~g}$ xylan, $0.3 \mathrm{~g}$ sodium pyruvate, $0.3 \mathrm{~g} \mathrm{~K}_{2} \mathrm{HPO}_{4}, 0.05 \mathrm{~g} \mathrm{MgSO}_{4}, 0.05 \mathrm{~g}$ $\mathrm{CaCl}_{2}$ and $15 \mathrm{~g}$ agar). The plates were incubated at $30{ }^{\circ} \mathrm{C}$ for 1 month. Single colonies were purified by transferring them onto new plates (modified R2A medium) for further incubation. Strain Gsoil $954^{\mathrm{T}}$ was one of the isolates that appeared on the modified R2A agar plates under aerobic conditions. It was routinely cultured on modified R2A agar at $30{ }^{\circ} \mathrm{C}$ and maintained as a glycerol suspension $(20 \%$, w/v) at $-70{ }^{\circ} \mathrm{C}$.

The Gram reaction was tested by using the non-staining method as described by Buck (1982). Cell morphology and motility were investigated with a Nikon light microscope ( $\times 1000$ magnification), using cells grown on R2A agar for 3 days at $30{ }^{\circ} \mathrm{C}$. Catalase and oxidase tests were performed as outlined by Cappuccino \& Sherman (2002). Acid production from 49 carbon sources was tested at $30{ }^{\circ} \mathrm{C}$ with API $50 \mathrm{CH}$ in combination with API $50 \mathrm{CHB} / \mathrm{E}$ medium (bioMérieux). Growth at a variety of temperatures $\left(4,15,20,25,30,37,42\right.$ and $\left.45^{\circ} \mathrm{C}\right)$ was assessed on R2A agar. Growth at a variety of $\mathrm{pH}$ values was assessed in $\mathrm{R} 2 \mathrm{~A}$ 
broth (Difco). Utilization of substrates as sole carbon sources and some physiological characteristics were determined with API ID32 GN, API 20NE and API 20E galleries according to the instructions of the manufacturer (bioMérieux). Phosphate uptake was measured as described by Nakamura et al. (1995). Tests for degradation of DNA [DNase activity; using DNase agar (Scharlau) and flooding plates with $1 \mathrm{M} \mathrm{HCl}$, casein, chitin, starch (Atlas, 1993), lipids (Kouker \& Jaeger, 1987), xylan and cellulose (Ten et al., 2004) were performed and evaluated after 10 days. Salt tolerance was tested with R2A broth supplemented with $1-10 \%(\mathrm{w} / \mathrm{v}) \mathrm{NaCl}$ after 5 days incubation. Growth on nutrient agar, trypticase soy agar and MacConkey agar was also evaluated at $30{ }^{\circ} \mathrm{C}$.

Cells of strain Gsoil $954^{\mathrm{T}}$ were aerobic, Gram-positive, non-endospore-forming, non-motile and coccus-shaped. Colonies grown on R2A agar plates for 5 days were smooth, circular, non-glossy, yellowish in colour and 1$2 \mathrm{~mm}$ in diameter. Physiological and biochemical characteristics of strain Gsoil $954^{\mathrm{T}}$ are summarized in the species description. Selected characteristics that serve to differentiate strain Gsoil $954^{\mathrm{T}}$ from related species of the genus Microlunatus are shown in Table 1.
For measurement of the $\mathrm{G}+\mathrm{C}$ content of the chromosomal DNA, genomic DNA of the novel strain was extracted and purified as described by Moore \& Dowhan (1995), enzymically degraded into nucleosides and then determined as described by Mesbah et al. (1989) using reversedphase HPLC. Isoprenoid quinones were extracted with chloroform/methanol $(2: 1, \mathrm{v} / \mathrm{v})$, evaporated under a vacuum and re-extracted in $\mathrm{n}$-hexane/water $(1: 1, \mathrm{v} / \mathrm{v})$. The crude n-hexane-quinone solution was purified using Sep-Pak Vac silica cartridges (Waters) and subsequently analysed using HPLC as described previously (Hiraishi et al., 1996). Cellular fatty acids were determined for strains harvested from R2A (Difco) agar plates after 5 days incubation. The cellular fatty acids were saponified, methylated and extracted according to the protocol of the Sherlock Microbial Identification System (MIDI). The fatty acids were analysed using a gas chromatograph (model 6890; Hewlett Packard) and were identified using the Microbial Identification software package (Sasser, 1990). Diaminopimelic acid isomers in the cell-wall peptidoglycan were determined by using TLC after hydrolysis with $6 \mathrm{M} \mathrm{HCl}$ at $100{ }^{\circ} \mathrm{C}$ for $18 \mathrm{~h}$, as described by Komagata \& Suzuki (1987). Polar lipids were extracted

Table 1. Characteristics that differentiate strain Gsoil $954^{\top}$ from M. ginsengisoli and M. phosphovorus

Strains: 1, Gsoil 954 ${ }^{\mathrm{T}}$; 2, M. ginsengisoli Gsoil $633^{\mathrm{T}}$ (data from Cui et al., 2007); 3, M. phosphovorus KCTC $9798^{\mathrm{T}}$ (data from Nakamura et al., 1995). All of the strains were Gram-positive, non-endospore-forming, non-motile, cocci-shaped bacteria. All of the strains could reduce nitrate to nitrite under aerobic conditions. All of the strains were positive for $\beta$-glucosidase activity and utilization of $\mathrm{D}$-glucose, $\mathrm{D}$-mannose, $\mathrm{L}$-arabinose, maltose and melibiose as sole carbon sources. All of the strains were negative for the utilization of glycerol as a carbon source. All of the strains were positive for catalase activity. +, Positive; -, negative; DPG, diphosphatidylglycerol; PE, phosphatidylethanolamine; PG, phosphatidylglycerol; PI, phosphatidylinositol; PL, unidentified phospholipid(s).

\begin{tabular}{|lccc|}
\hline Characteristic & $\mathbf{1}$ & $\mathbf{2}$ & $\mathbf{3}$ \\
\hline Temperature range $\left({ }^{\circ} \mathrm{C}\right)$ & $20-30$ & $20-30$ & $5-35$ \\
Oxidase & + & - & + \\
Nitrate reduction under anaerobic & - & - & + \\
conditions & & - & + \\
Phosphate uptake & - & - & + \\
Utilization as a sole carbon source & & + & + \\
Acetate & - & + & + \\
Cellobiose & - & + & + \\
Dulcitol & - & + & - \\
Galactose & - & - & - \\
Glycogen & - & + & + \\
Inositol & - & - & + \\
Lactose & - & - & + \\
Mannitol & - & + & PI, PG, DPG, PL \\
Starch & - & PG, DPG, PE, PL & 67.9 \\
D-Xylose & PG, DPG, PE & 69.9 & \\
Polar lipids & 65.1 & & + \\
DNA G + C content $(m o l \%)$ & & & + \\
\end{tabular}

${ }^{\star}$ Data from Maszenan et al. (1999). 
and examined using two-dimensional TLC (Minnikin et al., 1977).

The $\mathrm{G}+\mathrm{C}$ content of genomic DNA of strain Gsoil $954^{\mathrm{T}}$ was $65.1 \mathrm{~mol} \%$. MK-9 $\left(\mathrm{H}_{4}\right)$ was the predominant respiratory menaquinone. The cell-wall peptidoglycan of strain Gsoil $954^{\mathrm{T}}$ contained LL-diaminopimelic acid. The polar lipids detected were phosphatidylethanolamine, diphosphatidylglycerol and phosphatidylglycerol; phosphatidylethanolamine is rarely found in members of the family Propionibacteriaceae (Maszenan et al., 1999), so this difference could serve to differentiate strain Gsoil $954^{\mathrm{T}}$ from Microlunatus phosphovorus (Table 2). As shown in Table 2, iso- $\mathrm{C}_{15: 0}$ and anteiso- $\mathrm{C}_{15: 0}$ constitute more than $60 \%$ of the total fatty acid content of strain Gsoil $954^{\mathrm{T}}$ and showed levels similar to those of the type strains of Microlunatus panaciterrae and M. phosphovorus. However, the presence of $\mathrm{C}_{17: 0}$ and $\mathrm{C}_{17: 1} \omega 8 c$, the absence of iso$\mathrm{C}_{14: 0}$ and iso- $\mathrm{C}_{15: 1} \mathrm{G}$ and the existence of some quantitative differences in fatty acid composition served to distinguish strain Gsoil $954^{\mathrm{T}}$ from the recognized members of the genus Microlunatus (Table 2).

PCR-mediated amplification of the 16S rRNA gene and sequencing of the purified PCR product were carried out as

Table 2. Cellular fatty acid profiles of strain Gsoil $954^{\top}$ and related type strains of species of the genus Microlunatus

Strains: 1, Gsoil $954^{\mathrm{T}} ; 2$, M. ginsengisoli Gsoil $633^{\mathrm{T}} ; 3$, M. phosphovorus KCTC $9798^{\mathrm{T}}$. Data for all strains are from this study. All strains were grown on R2A agar for 5 days at $30{ }^{\circ} \mathrm{C}$. ND, Not detected.

\begin{tabular}{|c|c|c|c|}
\hline Fatty acid & 1 & 2 & 3 \\
\hline \multicolumn{4}{|l|}{ Saturated } \\
\hline $\mathrm{C}_{14: 0}$ & ND & ND & 0.5 \\
\hline $\mathrm{C}_{15: 0}$ & 0.8 & 0.9 & 1.9 \\
\hline $\mathrm{C}_{16: 0}$ & ND & ND & 0.7 \\
\hline $\mathrm{C}_{17: 0}$ & 2.1 & 0.8 & ND \\
\hline \multicolumn{4}{|l|}{ Unsaturated } \\
\hline $\mathrm{C}_{17: 1} \omega 8 c$ & 8.8 & ND & ND \\
\hline \multicolumn{4}{|l|}{ Branched-chain } \\
\hline anteiso- $\mathrm{C}_{13: 0}$ & ND & 1.0 & ND \\
\hline iso- $\mathrm{C}_{14: 0}$ & $\mathrm{ND}$ & 8.2 & 8.9 \\
\hline iso- $\mathrm{C}_{15: 0}$ & 17.2 & 13.2 & 17.1 \\
\hline iso- $\mathrm{C}_{15: 1} \mathrm{G}$ & $\mathrm{ND}$ & 2.1 & $\mathrm{ND}$ \\
\hline anteiso- $\mathrm{C}_{15: 0}$ & 53.1 & 48.8 & 46.0 \\
\hline anteiso- $\mathrm{C}_{15: 1} \mathrm{~A}$ & 2.6 & 0.9 & $\mathrm{ND}$ \\
\hline iso- $\mathrm{C}_{16: 0}$ & 6.7 & ND & 15.3 \\
\hline iso- $\mathrm{C}_{16: 1} \mathrm{H}$ & ND & ND & 1.0 \\
\hline anteiso- $\mathrm{C}_{16: 0}$ & ND & ND & ND \\
\hline iso- $\mathrm{C}_{17: 0}$ & 2.7 & $\mathrm{ND}$ & 2.2 \\
\hline anteiso- $\mathrm{C}_{17: 0}$ & 3.1 & 2.6 & 1.2 \\
\hline \multicolumn{4}{|l|}{ Hydroxy } \\
\hline iso- $\mathrm{C}_{14: 0} 3-\mathrm{OH}$ & ND & ND & 3.93 \\
\hline Summed feature $4^{*}$ & 3.1 & ND & 1.3 \\
\hline
\end{tabular}

${ }^{\star}$ Summed feature 4 comprises $\mathrm{C}_{16: 1} \omega 7 c$ and/or iso- $\mathrm{C}_{15: 0}$ 2-OH. described by Kim et al. (2005). Almost-complete sequences of the 16S rRNA gene were compiled using SeqMan software (DNASTAR). The 16S rRNA gene sequences of representatives of related taxa were obtained from GenBank. Multiple alignments were performed with the CLUSTAL_X program (Thompson et al., 1997), gaps were edited in the BioEdit program (Hall, 1999) and evolutionary distances were calculated using the Kimura twoparameter model (Kimura, 1983). Phylogenetic trees were constructed by using a neighbour-joining method (Saitou \& Nei, 1987) and maximum parsimony (Fitch, 1971) with the MEGA3 program (Kumar et al., 2004); bootstrap values were based on 1000 replications (Felsenstein, 1985).

An almost-complete $16 \mathrm{~S}$ rRNA gene sequence (1454 bp) of strain Gsoil $954^{\mathrm{T}}$ was determined and subjected to comparative analysis. Phylogenetic analysis based on $16 \mathrm{~S}$ rRNA gene sequences indicated that strain Gsoil $954^{\mathrm{T}}$ belongs to the genus Microlunatus (Fig. 1). The closest phylogenetic neighbours of strain Gsoil $954^{\mathrm{T}}$ are Microlunatus ginsengisoli Gsoil $633^{\mathrm{T}}(96.4 \%)$ and $M$. phosphovorus DSM $10555^{\mathrm{T}}$ (96.2\%). The phylogenetic distance from any other recognized species within the family Propionibacteriaceae was less than $95.9 \%$. There is general agreement that a DNA-DNA relatedness level of approximately $70 \%$ is the threshold value for defining species (Wayne et al., 1987). On the basis of the available data, organisms that share less than $97.0 \% 16 \mathrm{~S}$ rRNA gene sequence similarity will not show more than $60 \%$ reassociation, irrespective of the hybridization method used (Stackebrandt \& Goebel, 1994; Keswani \& Whitman, 2001). Thus, the phylogenetic results for strain Gsoil $954^{\mathrm{T}}$ demonstrated that the strain was not related to any of the recognized members of the genus Microlunatus.

In summary, the morphological, biochemical and chemotaxonomic properties of strain Gsoil $954^{\mathrm{T}}$ are consistent with those described for the genus Microlunatus. On the basis of the relatively low 16S rRNA gene sequence similarities $(<97 \%)$ and the combination of unique phenotypic characteristics (Table 1), strain Gsoil $954^{\mathrm{T}}$ represents a novel species of the genus Microlunatus, for which the name Microlunatus panaciterrae sp. nov. is proposed.

\section{Description of Microlunatus panaciterrae sp. nov.}

Microlunatus panaciterrae (pa.na.ci.ter'rae. N.L. n. Panax -acis scientific name for ginseng; L. n. terra soil; N.L. gen. n. panaciterrae of soil of a ginseng field).

Cells are Gram-positive, strictly aerobic, non-motile, coccus-shaped and $0.3-0.7 \mu \mathrm{m}$ in diameter after $24 \mathrm{~h}$ culture on R2A agar plates. Colonies grown on R2A agar for 5 days are smooth, circular, non-glossy, yellowish, convex and $1-2 \mathrm{~mm}$ in diameter. Grows well at $20-30{ }^{\circ} \mathrm{C}$ and at $\mathrm{pH}$ 5.0-9.0, but does not grow at temperatures below $15{ }^{\circ} \mathrm{C}$ or above $37{ }^{\circ} \mathrm{C}$. Grows on nutrient agar, but not on MacConkey agar or trypticase soy agar. Growth on $\mathrm{R} 2 \mathrm{~A}$ agar occurs in the absence of $\mathrm{NaCl}$ and in the presence 


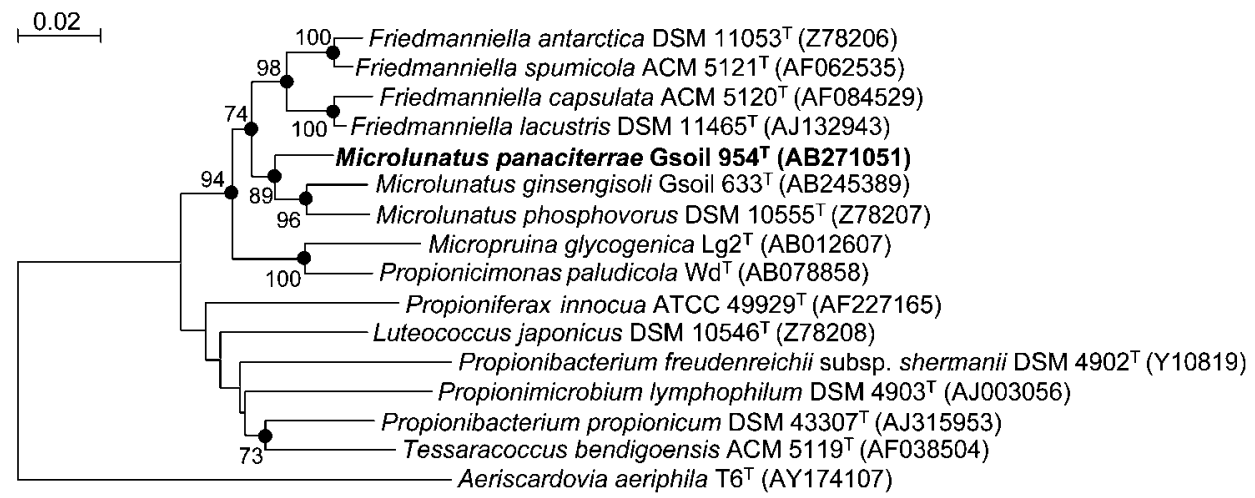

Fig. 1. Phylogenetic tree, based on $16 \mathrm{~S}$ rRNA gene sequences, showing the positions of strain Gsoil $954^{\top}$ and related species. This tree was constructed using the neighbour-joining method (Saitou \& Nei, 1987) with a Kimura (1983) twoparameter distance matrix and pairwise deletion. Filled circles indicate branches that were also recovered by using maximumparsimony algorithms. Bootstrap percentages (based on 1000 replications) $>70 \%$ are shown at branch points. Bar, 2 substitutions per 100 nucleotide positions.

of $5.0 \%(\mathrm{w} / \mathrm{v}) \mathrm{NaCl}$, but not with $6.0 \%(\mathrm{w} / \mathrm{v}) \mathrm{NaCl}$. Catalase and oxidase reactions are positive. $\mathrm{H}_{2} \mathrm{~S}$ is not produced. Nitrate is reduced under aerobic conditions, but nitrite is not reduced. Anaerobic growth does not occur; nitrate is not reduced under anaerobic conditions. In API $20 \mathrm{E}$ tests, negative results are obtained for urease, arginine dihydrolase, lysine decarboxylase, ornithine decarboxylase and tryptophan deaminase; positive results are obtained for $\beta$-galactosidase, $\beta$-glucosidase, gelatinase and in the VogesProskauer reaction. Acid is produced from amygdalin, Larabinose, D-glucose, melibiose and L-rhamnose. Acid is not produced from inositol, D-mannitol, D-sorbitol or sucrose. The following compounds are utilized as sole carbon sources: D-arabinose, citrate, D-fucose, L-fucose, Dglucose, lactate, maltose, D-mannose, melibiose, L-rhamnose, D-ribose, salicin, D-sorbitol and sucrose. The following compounds are not utilized as sole carbon sources: $N$-acetylglucosamine, adipate, D-adonitol, alanine, starch, amygdalin, D-arabitol, L-arabitol, arbutin, caprate, cellobiose, dulcitol, erythritol, D-fructose, galactose, glycogen, glycerol, gluconate, histidine, 3-hydroxybenzoate, 4hydroxybenzoate, 3-hydroxybutyrate, inositol, inulin, itaconate, 2-ketogluconate, 5-ketogluconate, D-lactose, Dlyxose, malate, malonate, D-mannitol, melezitose, methyl $\alpha$-D-glucopyranoside, methyl $\alpha$-D-mannopyranoside, methyl $\beta$-D-xylose, phenylacetate, proline, propionate, raffinose, serine, sodium acetate, L-sorbose, suberate, $\mathrm{D}$ tagatose, trehalose, turanose, valerate, xylitol and Lxylose. Xylan, chitin, cellulose, casein, olive oil and DNA are not degraded, but starch is degraded. MK$9\left(\mathrm{H}_{4}\right)$ is the predominant menaquinone. The major cellular fatty acids are anteiso- $\mathrm{C}_{15: 0}$, iso- $\mathrm{C}_{15: 0}$, iso- $\mathrm{C}_{17: 0}$ and iso- $\mathrm{C}_{16: 0}$. The cell-wall peptidoglycan contains LLdiaminopimelic acid. The polar lipids detected are phosphatidylethanolamine, diphosphatidylglycerol and phosphatidylglycerol.
The type strain, Gsoil $954^{\mathrm{T}} \quad\left(=\mathrm{KCTC} \quad 13058^{\mathrm{T}}=\mathrm{DSM}\right.$ $18662^{\mathrm{T}}$ ), was isolated from soil from a ginseng field in Pocheon Province, South Korea. The DNA G+C content of the type strain is $65.1 \mathrm{~mol} \%$ (as determined by HPLC).

\section{Acknowledgements}

We thank Jean Euzéby for his help with the etymology of the species epithet.

\section{References}

Atlas, R. M. (1993). Handbook of Microbiological Media. Edited by L. C. Parks. Boca Raton, FL: CRC Press.

Buck, J. D. (1982). Nonstaining (KOH) method for determination of Gram reactions of marine bacteria. Appl Environ Microbiol 44, 992993.

Cappuccino, J. G. \& Sherman, N. (2002). Microbiology: a Laboratory Manual, 6th edn. San Francisco: Pearson Education, Inc. and Benjamin Cummings.

Cui, Y.-S., Im, W.-T., Yin, C.-R., Yang, D.-C. \& Lee, S.-T. (2007). Microlunatus ginsengisoli sp. nov. isolated from soil of a ginseng field. Int J Syst Evol Microbiol 57, 713-716.

Felsenstein, J. (1985). Confidence limit on phylogenies: an approach using the bootstrap. Evolution 39, 783-791.

Fitch, W. M. (1971). Toward defining the course of evolution: minimum change for a specific tree topology. Syst Zool 20, 406-416.

Hall, T. A. (1999). BioEdit: a user-friendly biological sequence alignment editor and analysis program for Windows 95/98/NT. Nucleic Acids Symp Ser 41, 95-98.

Hiraishi, A., Ueda, Y., Ishihara, J. \& Mori, T. (1996). Comparative lipoquinone analysis of influent sewage and activated sludge by highperformance liquid chromatography and photodiode array detection. J Gen Appl Microbiol 42, 457-469.

Keswani, J. \& Whitman, W. B. (2001). Relationship of $16 \mathrm{~S}$ rRNA sequence similarity to DNA hybridization in prokaryotes. Int J Syst Evol Microbiol 51, 667-678. 
Kim, M. K., Im, W.-T., Ohta, H., Lee, M. \& Lee, S.-T. (2005). Sphingopyxis granuli sp. nov., a $\beta$-glucosidase-producing bacterium in the family Sphingomonadaceae in $\alpha-4$ subclass of the Proteobacteria. J Microbiol 43, 152-157.

Kimura, M. (1983). The Neutral Theory of Molecular Evolution. Cambridge: Cambridge University Press.

Komagata, K. \& Suzuki, K. (1987). Lipids and cell-wall analysis in bacterial systematics. Methods Microbiol 19, 161-207.

Kouker, G. \& Jaeger, K.-E. (1987). Specific and sensitive plate assay for bacterial lipase. Appl Environ Microbiol 53, 211-213.

Kumar, S., Tamura, K. \& Nei, M. (2004). MEGA3: integrated software for molecular evolutionary genetics analysis and sequence alignment. Brief Bioinform 5, 150-163.

Maszenan, A. M., Seviour, R. J., Patel, B. K. C., Schumann, P., Burghardt, J., Webb, R. I., Soddell, J. A. \& Rees, G. N. (1999). Friedmanniella spumicola sp. nov. and Friedmanniella capsulata sp. nov. from activated sludge foam: Gram-positive cocci that grow in aggregates of repeating groups of cocci. Int J Syst Bacteriol 49, 1667-1680.

Mesbah, M., Premachandran, U. \& Whitman, W. B. (1989). Precise measurement of the $\mathrm{G}+\mathrm{C}$ content of deoxyribonucleic acid by highperformance liquid chromatography. Int J Syst Bacteriol 39, 159-167.

Minnikin, D. E., Patel, P. V., Alshamaony, L. \& Goodfellow, M. (1977). Polar lipid composition in the classification of Nocardia and related bacteria. Int J Syst Bacteriol 27, 104-117.

Moore, D. D. \& Dowhan, D. (1995). Preparation and analysis of DNA. In Current Protocols in Molecular Biology, pp. 2-11. Edited by F. W.
Ausubel, R. Brent, R. E. Kingston, D. D. Moore, J. G. Seidman, J. A. Smith \& K. Struhl. New York: Wiley.

Nakamura, K., Hiraishi, A., Yoshimi, Y., Kawaharasaki, M., Masuda, K. \& Kamakata, Y. (1995). Microlunatus phosphovorus gen. nov., sp. nov., a new gram-positive polyphosphate-accumulating bacterium isolated from activated sludge. Int J Syst Bacteriol 45, 17-22.

Saitou, N. \& Nei, M. (1987). The neighbor-joining method: a new method for reconstructing phylogenetic trees. Mol Biol Evol 4, 406-425.

Sasser, M. (1990). Identification of bacteria by gas chromatography of cellular fatty acids, MIDI Technical Note 101. Newark, DE: MIDI Inc.

Stackebrandt, E. \& Goebel, B. M. (1994). Taxonomic note: a place for DNA-DNA reassociation and $16 \mathrm{~S}$ rRNA sequence analysis in the present species definition in bacteriology. Int J Syst Bacteriol 44, 846-849.

Ten, L. N., Im, W.-T., Kim, M.-K., Kang, M.-S. \& Lee, S.-T. (2004). Development of a plate technique for screening of polysaccharidedegrading microorganisms by using a mixture of insoluble chromogenic substrates. J Microbiol Methods 56, 375-382.

Thompson, J. D., Gibson, T. J., Plewniak, F., Jeanmougin, F. \& Higgins, D. G. (1997). The CLUSTAL_X windows interface: flexible strategies for multiple sequence alignment aided by quality analysis tools. Nucleic Acids Res 25, 4876-4882.

Wayne, L. G., Brenner, D. J., Colwell, R. R., Grimont, P. A. D., Kandler, O., Krichevsky, M. I., Moore, L. H., Moore, W. E. C., Murray, R. G. E. \& other authors (1987). International Committee on Systematic Bacteriology. Report of the ad hoc committee on reconciliation of approaches to bacterial systematics. Int J Syst Bacteriol 37, 463-464. 